Agropedology 2019, 29 (02), 76-85

doi.org/10.47114/j.agroped.2019.dec1

\title{
Remote Sensing and GIS-Based Soil Loss Assessment Using RUSLE Model -A Case Study of Bareli Watershed, Seoni District of Madhya Pradesh
}

\author{
Sagar N. Ingle ${ }^{1^{*}}$, M.S.S. Nagaraju, Nirmal Kumar, Nisha Sahu, Pramod Tiwary, \\ Rajeev Srivastava and Jagdish Prasad
}

ICAR-National Bureau of Soil Survey and Land Use Planning, Nagpur-440033, India
${ }^{1}$ Dr. Panjabrao Deshmukh Krishi Vidyapeeth, Akola- 444104, India

\begin{abstract}
A quantitative assessment of soil loss was done using Revised Universal Soil Loss Equation (RUSLE) model, remote sensing and digital elevation model (DEM) in integrated raster based GIS in Bareli watershed, Seoni district of Madhya Pradesh. GIS data layers including rainfall erosivity $(\mathrm{R})$, soil erodibility $(\mathrm{K})$, slope length and steepness (LS), cover management (C) and conservation practice (P) factors were computed and integrated to compute average annual soil loss in the watershed. The watershed has been delineated into very low $\left(<10 \mathrm{tha}^{-1} \mathrm{yr}^{-1}\right)$, low (10-25 tha $\left.\mathrm{yr}^{-1}\right)$, moderate (25-50 $\left.\mathrm{t} \mathrm{ha}^{-1} \mathrm{yr}^{-1}\right)$, severe (50-100 t ha $\left.\mathrm{yr}^{-1}\right)$ and very severe $\left(>100 \mathrm{t} \mathrm{ha}^{-1} \mathrm{yr}^{-1}\right)$ soil erosion classes. The study indicated that $63.8 \%$ of TGA is under very low to low followed by $14.3 \%$ of TGA under moderate soil erosion class. The severe and very severe erosion classes constitute $21.9 \%$ of TGA which warrant immediate attention for preparing strategies for soil and water conservation measures. Various soil and water conservation measures have been suggested based on landforms, soil, slope, land use and soil loss for sustainable management of land resources to improve the productivity of these lands.
\end{abstract}

Key words: Remote sensing, GIS, Soil loss, RUSLE, Soil and water conservation measures.

\section{Introduction}

Soil degradation and erosion are insidious processes, not readily apparent to farmers until the effects are severe and irreversible (Cleaver and Schrieber 1995). Deforestation, wastelands and indiscriminate usage of cultivable lands have collectively induced soil erosion resulting in ecological imbalances. Soil erosion will aggravate further with increasing population pressure, over-utilization of natural resources, faulty land and water management practices (Jena et al. 2015; Gelagay and Minale 2016). In many regions, unchecked soil erosion and associated land degradation have made vast areas economically unproductive. It leads to decline in soil fertility and brings a series of negative impacts to environment (Prasannakumar et al. 2012). Often, a quantitative assessment is needed to infer the extent and magnitude of soil erosion problems so that effective management strategies can be resorted to. But, the complexity of the variables makes precise estimation or prediction of erosion difficult. The latest advances in spatial information technology have augmented the existing methods and have provided efficient methods of analysis, monitoring and management of natural resources. Remote sensing data along with Digital

*Corresponding author: (Email: sagarsoils26@gmail.com ) 
Elevation model (DEM) and GIS can be successfully used to enable rapid as well as detailed assessment of erosion hazards (Jain et al. 2001; Srinivas et al. 2002; Kouli et al. 2009; Nagaraju et al. 2011).

The most popular empirical models applied worldwide to estimate the soil erosion is Revised Universal Soil Loss Equation (RUSLE) (Wischmeier and Smith 1978), which is a conservation planning tool that has been demonstrated to do a reasonably good job for estimating soil erosion for many disturbed land uses (Moore and Wilson 1992; Millward and Mersey 1999). Choosing the data for variables of RUSLE and generating the layers for spatial assessment of soil erosion are critical tasks. However, geographical information system (GIS) has augmented the RUSLE and permits effective and accurate application of the model. Renschler et al. (1999) and Thelkar et al. (2019) used RUSLE to predict the magnitude and spatial distribution of soil erosion using GIS software. Yang et al. (2003) employed a GIS-based RUSLE model to simulate global soil erosion.

The Seoni district of Madhya Pradesh experiences frequent erratic rainfall with continuous depletion of vegetative cover and increase in soil erosion with low crop productivity. The objective of the study is to compute quantitative soil loss and suggest suitable soil and water conservation measures by integrating the information of soil, climatic data, remote sensing data and digital elevation model (DEM) using RUSLE model in GIS environment in Bareli watershed of Seoni district of Madhya Pradesh to enhance the productivity of land resources on sustainable basis.

\section{Materials and Methods}

\section{Studyarea}

Bareli watershed in Seoni district of Madhya Pradesh ( $22^{\circ} 29^{\prime} 39^{\prime \prime}$ to $22^{\circ} 32^{\prime} 10^{\prime \prime} \mathrm{N}, 79^{\circ} 46^{\prime} 44^{\prime \prime}$ to $79^{\circ}$ $49^{\prime} 50^{\prime}$ E) covers an area of 1795.35 ha (Fig. 1). The elevation of the area ranges from 520 to $620 \mathrm{~m}$ above mean sea level (MSL). Five major landforms viz., Plateau, Escarpment, Hills and Ridges, Isolated Mound and Pediments, associated with basalt, have been identified. The climate is dry sub-tropical with mean annual temperature of $28.4^{\circ} \mathrm{C}$ and mean annual rainfall of $1100 \mathrm{~mm}$. The area qualifies for ustic soil moisture regime and hyperthermic soil temperature regime. The natural vegetation comprises of Tectona grandis, Acacia spp., Butea frandosa, Buchanania lanzan, Ziziphus jujuba etc. The major crops are paddy (Oryza sativa), pigeonpea (Cajanus cajan), maize (Zea mays) and safflower (Carthamus tinctorius) in kharif and wheat (Triticum aestivum) and gram (Cicer arietinum) are grown under protective irrigation or stored moisture in rabi. Mango, Guava and custard apple are the main fruit crops of the area.

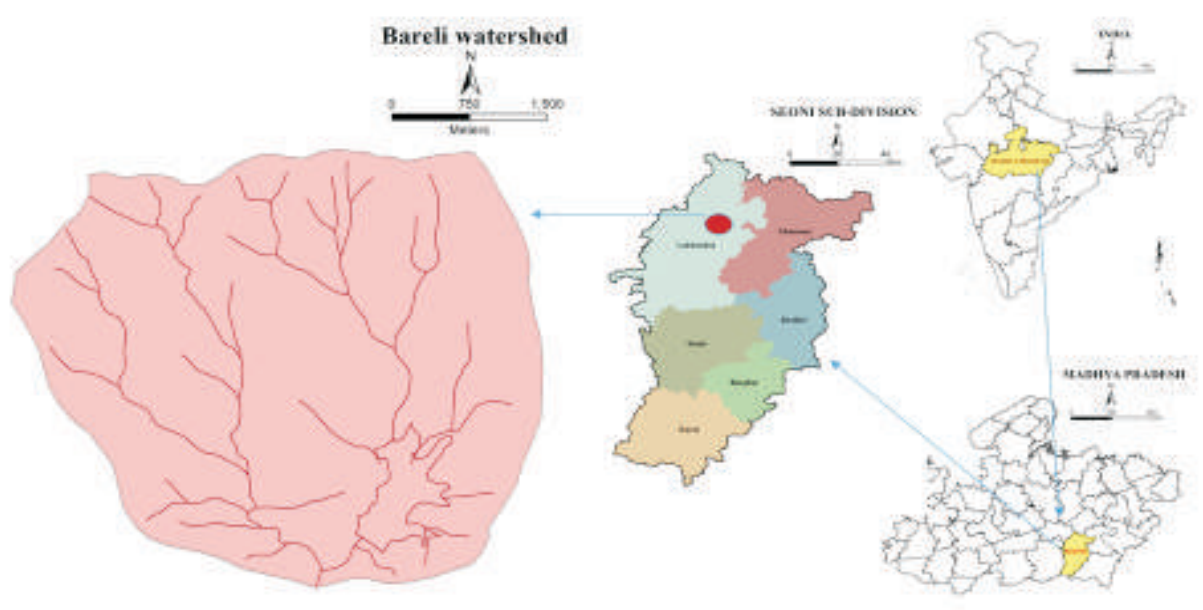

Fig. 1. Location map of Bareli watershed 
The RUSLE model was applied which requires rainfall characteristics, soil properties, land use land cover, topographic information, and conservation and management practices of the area. The advantage of
RUSLE is that the parameters of this model can easily be integrated with GIS for better analysis. The parameters of RUSLE model have been estimated based on the rainfall events, DEM, soil type and land cover.

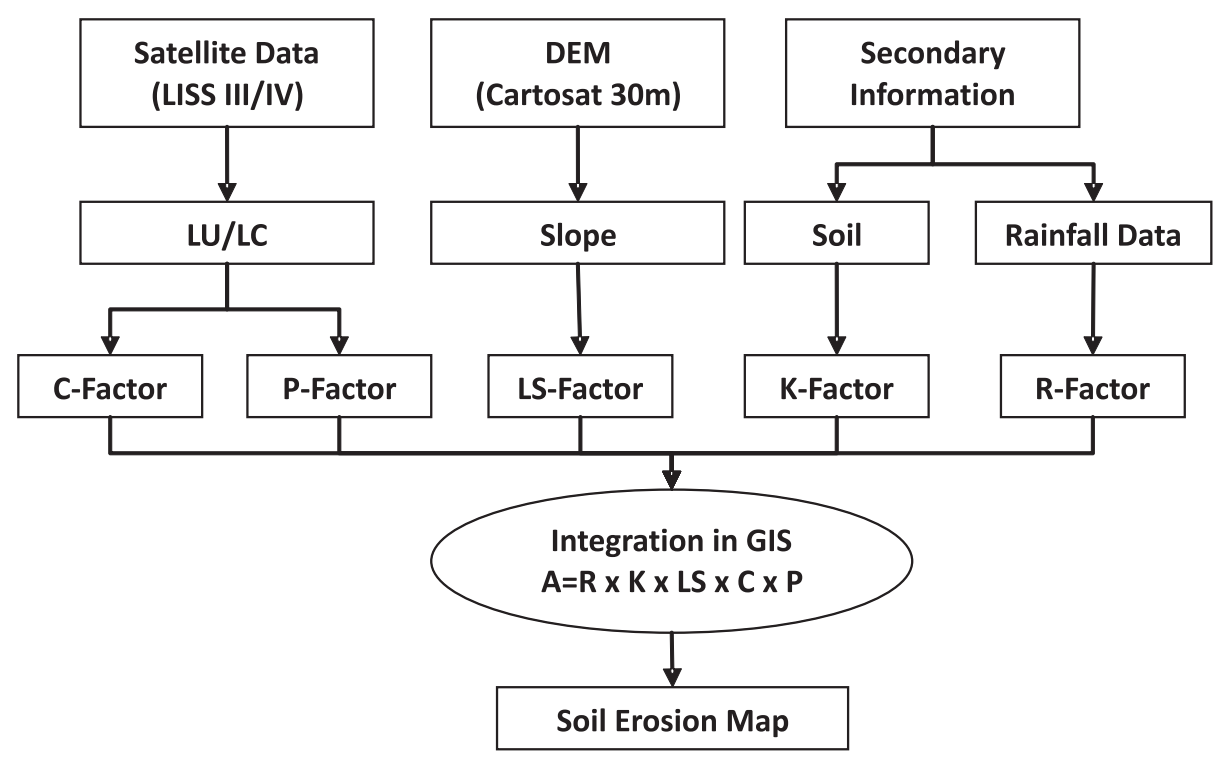

Fig. 2. Conceptual framework of soil loss analysis by RUSLE model

Data Sets used

\section{Landforms}

Five major landforms (plateau, escarpments, hills and ridges, isolated mounds and pediments) were identified in the watershed.

\section{Land use/land cover}

The visual interpretation of IRS-P6 LISS-IV and IRS-P6 LISS-III FCC led to the identification and delineation of five land use/land cover categories such as single crop, double crop, forest, wasteland and habitation (Fig.3a).

Slope

Slope information has been derived from Cartosat-1 digital elevation model (DEM). Five slope classes viz., very gently sloping (1-3\%), gently sloping (3-5\%), moderately sloping (5-10\%), strongly sloping $(10-15 \%)$ and moderately steeply sloping (15-25\%) lands were identified (Fig.3b).

Soils

Five soil series, namely, Diwartola, Diwara, Bareli-1, Bareli-2 and Bareli-3 were tentatively identified during soil survey of the watershed. The clayey soils of Diwartola (Lithic Haplustepts) are shallow, well drained and very dark greyish brown (10YR 3/2M) in colour with moderate erosion. The soils of Diwara are shallow, well drained, very dark greyish brown (7.5YR 3/3M), clay soils with moderate erosion and qualify for Lithic Ustorthents at subgroup level. Soils of Bareli-1 are moderately deep, well drained, very dark greyish brown (10YR 3/2M), clay soils with severe erosion. Soils of Bareli-2 are shallow, well drained, very dark greyish brown (10YR 3/2M), clay soils underlain by hard basalt with moderate erosion and qualify for Lithic Ustorthents at subgroup level. Soils of Bareli-3 are moderately deep, well drained, dark greyish brown (7.5YR 3/3M), calcareous, clay soils with severe erosion and qualify for Typic Ustorthents at subgroup level (Fig.3c). The soils of all the series has substratum of saprolite layer of varying depth followed by hard basalt within $50 \mathrm{~cm}$.

Rainfall

Rainfall data was collected from the nearby rain gauge stations and the point data was brought in to ArcGIS, interpolated and a surface map was prepared (Fig.3d). 


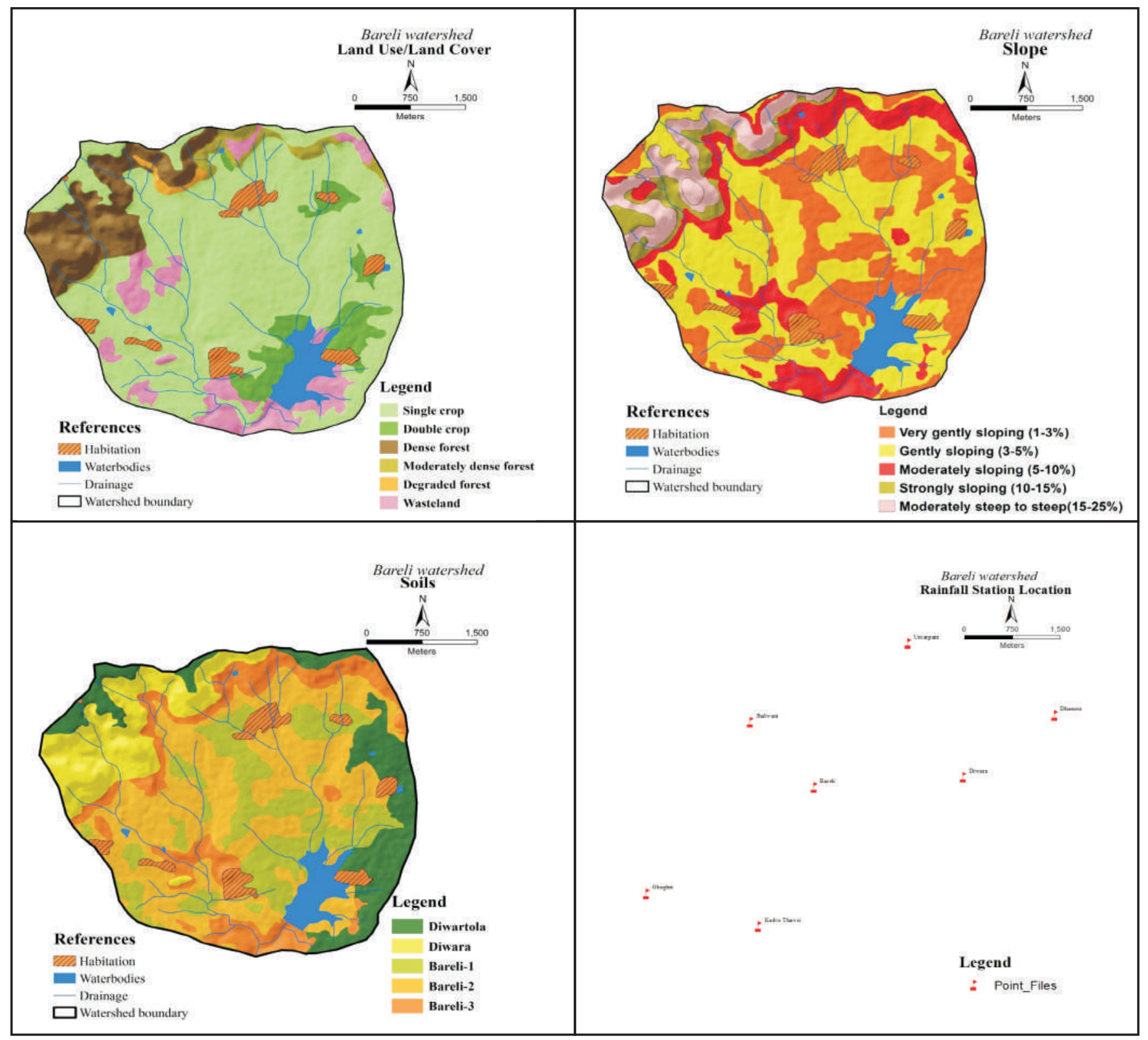

Fig. 3. a) Land use/land cover, b) slope, c) Soils, d) Rainfall stations

\section{Methodology}

\section{RUSLE Model}

The RUSLE has been widely used to predict the average annual soil loss by introducing the improved means of computing the soil erosion factors (Wischmeier and Smith 1978; Renard et al. 1996). The Bareli watershed was delineated from Survey of India (SOI) toposheet (1:50,000 scale) using ArcGIS 10.3 software. The prepared base map was then used for the extraction of satellite image (IRS-P6 LISS-IV) (November, 2013) with a spatial resolution of $5.8 \mathrm{~m}$ along with LISS-III (March, 2012) with a spatial resolution of $23.5 \mathrm{~m}$ and used for assessment of vegetation parameters in the area. Cartosat-1 DEM with a resolution of $30 \mathrm{~m}$ was used for deriving slope information. RUSLE model equation is represented by: 
$\mathrm{A}=\mathrm{R} \times \mathrm{K} \times \mathrm{LS} \times \mathrm{C} \times \mathrm{P}$

where, $\mathrm{A}$ is the computed spatial average of soil loss over a period selected for R, usually on yearly basis $\left(\mathrm{tha}^{-1} \mathrm{y}^{-1}\right) ; \mathrm{R}$ is the rainfall erosivity factor $\left(\mathrm{MJ} \mathrm{mm} \mathrm{ha}{ }^{-1} \mathrm{~h}\right.$ $\left.{ }^{1} \mathrm{y}^{-1}\right)$; $\mathrm{K}$ is the soil erodibility factor $\left(\mathrm{tha}^{-1} \mathrm{MJ}^{-1} \mathrm{~mm}^{-1}\right)$; LS is the slope length steepness factor (dimensionless); $\mathrm{C}$ is the cover management factor (dimensionless, ranging between 0 and 1.5); and $\mathrm{P}$ is the erosion control (conservation support) practices factor (dimensionless, ranging between 0 and 1 ).

\section{Rainfall Erosivity Factor (R)}

$\mathrm{R}$ is the long term annual average of the product of event rainfall kinetic energy and the maximum rainfall intensity in 30 minutes in $\mathrm{mm} \mathrm{hrs}^{-1}$. Using the data for storms from several rain gauge stations located in different zones, linear relationships were established between average annual rainfall and computed EI30 values for different zones of India and iso-erodent maps were drawn for annual and seasonal EI30 values (Singh et al. 1981). The derived relationship is given below:

$\mathrm{R}=79+0.363 \mathrm{R}_{\mathrm{N}}$

where, $R_{N}$ is the average annual rainfall in $\mathrm{mm}$.

\section{Soil Erodibility Factor (K)}

This factor conveys the rate at which different soils erode. Erodibility is a function of soil texture, organic matter content and permeability. A widely used relationship for predicting erodibility is by monograph given by Wischmeier et al. (1978) and the relationship is given below.

$$
\mathrm{K}=\frac{\left(2.1 \times 10^{-4}(12-\mathrm{OM}) \mathrm{M}^{1.14}+3.25(\mathrm{~s}-2)+2.5(\mathrm{p}-3)\right.}{759.4} \ldots
$$

where, OM is organic matter, $\mathrm{s}$ is structural code, $\mathrm{p}$ is permeability code and $\mathrm{M}$ is calculated as follows :

$\mathrm{M}=(\%$ silt $+\%$ very fine sand $) \times(100-\%$ clay $) \ldots(4)$

Slope length-Steepness Factor (LS)

Slope length-steepness (LS) factor accounts for the effect of topography on sheet and rill erosion. The two parameters that constitute the topographic factor are slope gradient and slope length factor and can be estimated through field measurement or from a digital elevation model (DEM). Since the magnitude of erosion is influenced by the angle and the length of slope, they must be considered together. There are many relationships for the estimation of LS factor, but the best suited for integration with GIS was proposed by Moore and Bruch (1985) and explored by Mitasova and Mitas (1999) and Simms et al. (2003) based on unit stream power theory. The equation is as follows:

$$
\mathrm{LS}=\left(\frac{\mathrm{A}}{22.13}\right) 0.6+\left(\frac{\operatorname{Sin} \mathrm{B}}{0.0896}\right) 1.3
$$

where, $\mathrm{A}$ is a slope length factor and $\mathrm{B}$ is the slope steepness factor; 22.13 is RUSLE unit plot length; 0.6 is a variable slope-length exponent (usually taken from respective grid).

$\mathrm{A}=$ Flow accumulation $\times$ Grid size

$\mathrm{B}=$ Slope of DEM

\section{Crop Management Factor (C)}

This factor represents the effect of soil disturbing activities, plants, crop sequence and productivity level, soil cover and sub-surface bio-mass on soil erosion. It is defined as the ratio of soil loss from land cropped under specific conditions to the corresponding loss from clean-tilled, continuous fallow (Wischmeier and Smith 1978). Since there are a variety of land covers and spatial and temporal changes, a set of satellite data sets from different periods were used to prepare a land use land cover map. Water bodies comprise ponds with and without vegetation, river, dry river, canal, swamps will have minimal erosion hence they are assigned a very low value (e.g. 0.003); for builtup area the chances of erosion can be considered null. Crop cultivation will have more chances of erosion and hence, they are assigned a higher value (e.g. 0.5). The $\mathrm{C}$ factor compiled from literature is shown in (Table1). 
Table 1. C factor for different land use classes in Bareli watershed

\begin{tabular}{lll}
\hline Sr. No. & Land use/Cover type & C factor \\
\hline 1 & Degraded Forest & 0.6 \\
\hline 2 & Dense Forest & 0.1 \\
\hline 3 & Double Crop & 0.4 \\
\hline 4 & Moderately Dense Forest & 0.25 \\
\hline 5 & Settlements & 0.09 \\
\hline 6 & Single Crop & 0.5 \\
\hline 7 & Wasteland & 1 \\
\hline 8 & Water body & 0 \\
\hline
\end{tabular}

Source: Reddy et al. (2016)

\section{Support Practice Factor $(P)$}

This factor relates to the practices which will aid in reducing water runoff and thus reducing the effective soil erosion. The better the supporting practices for conservation, the lower will be the value of $\mathrm{P}$. The $\mathrm{P}$ value ranges from 0 to 1 , where, 0 represents very good man-made erosion resistance facility and 1 represents no man-made erosion resistance facility. The support practice factor expresses the effect of support practices such as contour cultivation, strip cropping, arable land terrace and bench terrace and it cannot be assessed from coarse resolution land use map. Hence, the $\mathrm{P}$ value is adopted as shown in table 2. The flowchart of the methodology used in the present study is presented in figure 2 .

Table 2. P values based on Land use/ land cover

\begin{tabular}{ll}
\hline Land use/land cover & P Value \\
\hline Agricultural fields with bunds & 0.28 \\
All other land use & 1 \\
\hline
\end{tabular}

\section{Results and Discussion}

Rainfall Erosivity Factor ( $R$ )

Many studies indicated that the soil erosion rate in the catchment is more sensitive to rainfall. The daily rainfall is a better indicator of variation in the rate of soil erosion to characterize the seasonal distribution of sediment yield. While the advantage of using annual rainfall includes its ready availability, ease of computation and greater regional consistency of the exponent. Therefore, in the present analysis, average annual rainfall was used for $\mathrm{R}$ factor computation. Rain fall erosivity (R) value ranged from 479 to 488 (Fig. 4a).

\section{Soil Erodibility Factor (K)}

$\mathrm{K}$ factor values were assigned by using equation (3) to respective soil types in soil map to generate the soil erodibility map. The values of $\mathrm{K}$ factor are found to be ranging between 0.24 to 0.31 (Fig. $4 b$ ).

Slope length-Steepness Factor (LS)

The topographic component of RUSLE computed using Eq. (5) ranged from 0 (gentle slopes at 
lower and middle part) to 57.0 (steeper slopes at upper part). The topographic (LS) factor of RUSLE has, therefore, significant influence in the upper part of the watershed and vice versa in the lower and middle part (Fig. 4c).

\section{Crop Management Factor (C)}

Information on land use/land cover permits a better understanding of the land utilization aspects of cropping pattern, fallow land, forest, wasteland and surface water bodies, which are vital for developmental planning/erosion studies. Remote sensing and GIS technique has a potential to generate a thematic layer of land use-land cover of a region. The area has been classified into eight land use classes. The land use-land cover map was reclassified and a $\mathrm{C}$ factor map was generated. The $\mathrm{C}$ value ranged from 0 to 1 (Fig. $4 \mathrm{~d}$ ).

\section{Support Practice Factor $(P)$}

The $\mathrm{P}$ factor is the ratio of soil loss from a plot with a specific conservation practice to the corresponding loss from a plot with up and down cultivation under identical conditions. A conservation practice $(\mathrm{P})$ factor value of 1.0 was assigned to forest land. Based on field management practices, a P factor map was generated (Fig. 4 e). The results are in close conformity with Jena et al. (2018).

\section{Soil Loss Assessment}

The GIS analysis has been carried out for RUSLE to estimate annual soil loss on a pixel-by pixel basis and the spatial distribution of the soil erosion (Table 3 and Fig. 4f). Majority (38.5\%) of total geographical area (TGA) had very low risk erosion with an average annual soil loss of $<10 \mathrm{t} \mathrm{ha}^{-1} \mathrm{yr}^{-1}$ on nearly level $(0-1 \%)$ to very gentle slopes (1-3\%) followed by low soil erosion risk in $25.3 \%$ of TGA with a soil loss of 10-25 $\mathrm{t} \mathrm{ha}^{-1} \mathrm{yr}^{-1}$ associated with gently sloping (3-5\%) lands. The moderate, severe and very severe soil erosion risk classes constitute 14.3, 11.2 and 10.7 per cent, respectively. Many authors have followed similar classification system in defining the soil loss classes in India (Reddy et al. 2016) and (Jena et al. 2018) which needs immediate attention for developing strategies for soil and water conservation measures.

Table 3. Estimated rate of soil erosion in Bareli watershed

\begin{tabular}{|c|c|c|c|c|}
\hline \multirow{2}{*}{ Sr. No. } & \multirow{2}{*}{$\begin{array}{c}\text { Average annual } \\
\text { soil loss } \\
\left(\mathbf{t ~ h a}^{-1} \mathbf{y r}^{-1}\right) \\
\end{array}$} & \multirow{2}{*}{$\begin{array}{l}\text { Soil erosion risk } \\
\text { classes }\end{array}$} & \multicolumn{2}{|c|}{ Bareli Watershed } \\
\hline & & & Area (ha) & $\%$ of TGA \\
\hline 1 & $<10$ & Very low & 699.1 & 38.5 \\
\hline 2 & $10-25$ & Low & 459.4 & 25.3 \\
\hline 3 & $25-50$ & Moderate & 259.8 & 14.3 \\
\hline 4 & $50-100$ & Severe & 203.8 & 11.2 \\
\hline 5 & $>100$ & Very Severe & 193.5 & 10.7 \\
\hline
\end{tabular}



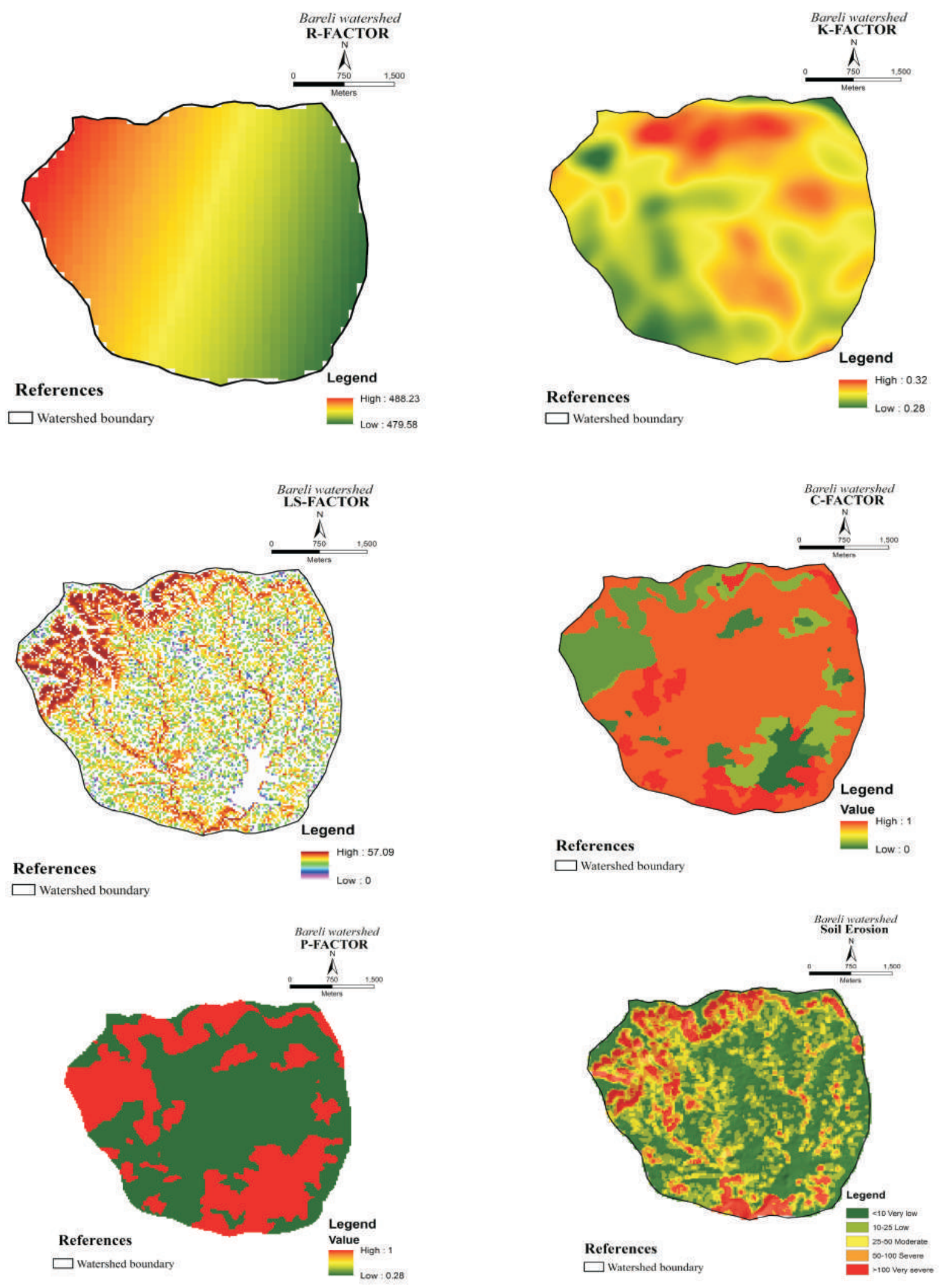

Fig. 4. a) R Factor, b) K Factor, c) LS Factor, d) C Factor, e) P factor and f) soil erosion map 


\section{Soil and water conservation measures}

The integration of landform, soil, present land use and slope maps under GIS environment resulted in thirteen composite land units which lead to identify the areas for resource development and conservation. The mapping units under plateau have fairly good cultivated lands with severe limitations of soil depth, surface stoniness, texture and coarse fragments. The soils are average in soil productivity and severely eroded as these lands are cultivated without any soil and water conservation measures. To improve the productivity in cultivated land units under single crop, agri-horticulture with gooseberry, guava, custard apple and drum stick may be adopted with integrated nutrient management and suitable soil and water conservation measures like contour bunding, gully plugging and water harvesting structures. The hills and ridges and isolated mounds cover 6.6 per cent of TGA and to improve the productivity of these lands, afforestation with locally adopted fast growing tree species are suggested. Continuous contour trenches need to be open up to reduce the runoff and in turn soil loss. The escarpments covering 6.7 per cent of TGA have shallow soils mostly under forest or rainfed crops in some land units. These units have strongly sloping $(10-15 \%)$ to moderately steep to steep sloping (15-25\%) lands with severe erosion. The area is suggested for afforestation and agroforestry with suitable tree species and NTF to maintain the ecological balance in the area. Staggered contour trenches needs to be constructed to reduce the run off and soil loss and retain more moisture in these land units. Pediments constitute 66.2 per cent of the watershed with shallow and moderately deep soils mainly under single crop with sorghum as major kharif crop and double crop with wheat and gram during rabi season. The mapping units have moderately to fairly good cultivated lands with severe limitations of soil depth, texture and surface stoniness. The soils are poor to average in soil productivity and moderately eroded without any soil and water conservation measures. Proper field bunding, gully plugging and contour bunding is needed to conserve soil and water. Agrihorticulture interventions like gooseberry, guava, custard apple and drum stick and silvipasture systems with multi-purpose trees with integrated nutrient management needs be taken up in these land units to improve the productivity.

\section{Conclusions}

The study concludes that moderate to very severe soil erosion risk areas constitute 36.2 per cent of the watershed. These areas include plateau, hills and ridges, steep to very steep sloping escarpments and moderately sloping pediments with severe limitations of soil depth and stoniness without any soil and water conservation measures and needs immediate attention. Various soil and water conservation measures have been suggested by taking into account the soil loss, landform, slope and present land use for sustainable management of land resources and to improve the productivity of these lands. The study helps in prioritizing the areas based on soil loss estimation for preparing strategies for soil and water conservation measures.

\section{References}

Cleaver, K. and Schrieber, G.A. (1995). Reversing the spiral: The population, agriculture and environment nexus in Sub-Saharan Africa. World Bank Report, Washington DC.

Gelagay, H.S. and Minale, A.S. (2016). Soil loss estimation using GIS and remote sensing techniques: A case of Koga watershed, Northwestern Ethiopia. International Soil and Water Conservation Research 4, 126-136.

Jain, S.K., Kumar, S. and Varghese, J. (2001). Estimation of soil erosion for a Himalayan watershed using GIS technique. Water Resources Management 15, 41-54

Jena, S.K., Kumar, A., Brahmanad, P.S., Mishra, A., Sahoo, N. and Patil, D.U. (2015). Design and development of rubber dams for watersheds in the climate change scenario. In 'Climate change modelling, planning and policy for agriculture.' (Eds. Singh, A.K., Dagar, J.C., Arunachalam, A., Gopichandran, R. and Shelat, K.N.) pp. 93-98.

Jena R.K., Padua, S., Ray, P., Ramachandran, S., Bandyopadhyay, S., Deb Roy, P., Reddy, 
G.P.O., Singh, S.K. and Ray, S.K. (2018). Assessment of soil erosion in sub-tropical ecosystem of Meghalaya, India using remote sensing, GIS and RUSLE. Indian Journal of Soil Conservation 46, 273-282.

Kouli, M., Soupios, P. and Vallianatos, F. (2009). Soil erosion prediction using the revised universal soil loss equation (RUSLE) in a GIS framework, Chania, North western Crete, Greece. Environmental Geology 57, 483-497.

Millward, A.A. and Mersey, J.E. (1999). Adapting the RUSLE to model soil erosion potential in a mountainous tropical watershed. Catena 38, $109 \mathrm{e} 129$

Mitasova, H. and Mitas, Z. (1999). Spatial modelling of soil detachment with RUSLE 3d. University of Illinois, Urbana-Champaign, USA.

Moore, D. and Wilson, J.P. (1992). Length - slope factors for the revised universal soil loss equation: Simplified method of estimation. Soil and Water Conservation 47, 423-428.

Moore, I.D. and Bruch, G.J. (1985). Physical basis of the length-slope factor in the universal soil loss equation. Soil Science Society of America 50, 1294-1298.

Nagaraju, M.S.S., Reddy, G.P.O., Maji, A.K., Srivastava, R., Raja, P. and Barthwal, A.K. (2011). Soil loss mapping for sustainable development and management of land resources in Warora tehsil of Chandrapur district of Maharashtra: An integrated approach using remote sensing and GIS. Journal of the Indian Society of Remote Sensing 39, 51-61.

Prasannakumar, V., Vijith, H., Geetha, N. and Shiny, R. (2012). Regional scale erosion assessment of a sub-tropical highland segment in the Western Ghats of Kerala, South India. Water Resources Management 25, 3715-3727.

Reddy, G.P.O., Kurothe, R.S., Sena, D.R., Harindranath, C.S., Niranjana, K.V., Naidu, L.G.K., Singh, S.K., Sarkar, D., Mishra, P.K. and Sharda, V.N. (2016). Assessment of soil erosion in tropical ecosystem of Goa, India using Universal Soil Loss Equation, geostatistics and GIS. Indian Journal of Soil Conservation 44, 1-7.
Renard, K.G., Foster, G.R., Weesies, G.A., McCool, D.K. and Yoder, D.C. (1996). Predicting soil erosion by water: A guide to conservation planning with the Revised Universal Soil Loss Equation (RUSLE). Hand book. No. 703. (Washington DC: USDA)

Renschler, C., Diekkrüger, B. and Mannaerts, C. (1999). Regionalization in surface runoff and soil erosion risk evaluation. IAHS Publication (International Association of Hydrological Sciences) 254, 233-241.

Simms, A.D., Woodroffe, C.D. and Jones, B.G. (2003). Application of RUSLE for erosion management in a coastal catchment, Southern NSW. In: Proceedings of the International Congresss on Modelling and Simulation: Integrative modelling of biophysical, social and economic systems for resource management solutions. pp. $678-683 .\left(14^{\text {th }}-17^{\text {th }}\right.$ July, Townsville, Australia).

Singh, G., Babu, R. and Chandra, S. (1981). Soil loss prediction research in India. Dehradun, India: Indian Council of Agricultural Research, Bulletin of Central Soil and Water Conservation Research and Training Institute No. T-12/D-9.

Srinivas, C.V., Maji, A.K., Reddy, G.P.O., and Chary, G.R. (2002). Assessment of soil erosion using remote sensing and GIS in Nagpur district, Maharashtra for prioritisation and delineation of conservation units. Journal of the Indian Society of Remote Sensing 30, 197-212.

Thelkar, S.I., Srivastava, R., Nagaraju, M.S.S., Jagdish Prasad, Chattaraj, S. and Obi-Reddy, G.P. (2019). Soil erosion assessment in basalticassociated landscapes of Central India using integrated approach of RUSLE, remote sensing and GIS. Journal of the Indian Society of Soil Science 67, 411-422.

Wischmeier, W.H. and Smith, D.D. (1978). Predicting rainfall erosion losses. USDA Agricultural Research Services Handbook, 537. (USDA: Washington, DC).

Yang, D., Kanae, S., Oki, T., Koikel, T. and Musiake, T. (2003). Global potential soil erosion with reference to land use and climate change. Hydrological Processes 17, 2913-2928. 